\title{
The co-disposal of colliery waste
}

\author{
S. Riley ${ }^{1}$, C. Gosling ${ }^{2}$ \& C. McQuade ${ }^{3}$ \\ ${ }^{1}$ Sustainable Engineering and Technology Group, \\ University of Western Sydney, NSW, Australia \\ ${ }^{2}$ Director, NCAGP Pty Ltd, Australia \\ ${ }^{3}$ Business Support, Zinifex Port Pirie Smelter, Australia
}

\begin{abstract}
Experiments conducted at Clarence Colliery into the potential for co-disposal of the two rejects from Clarence Colliery and Kable's Transport Sand Mine suggested that the co-disposal option was beneficial and mutually beneficial to the two companies. Column experiments were undertaken to simulate field conditions consisting of creating the required co-disposal arrangement and structure in containers, infiltrating water through each container and measuring the rates of infiltration and overflow and measuring the chemical properties of the leachate water. Geotechnical tests of co-disposal pile stability were undertaken using a specially constructed shear box. Layering the coal reject with clay tailings creates a semi-permeable barrier, which acts to restrict water percolation through the reject as well as reacting with the leachate to increase the leachate $\mathrm{pH}$ and adsorb metals.
\end{abstract}

Keywords: colliery waste disposal, coal, co-disposal.

\section{Introduction}

At the time of the study, Clarence Colliery, on the Newnes Plateau near Lithgow, NSW, used long wall mining techniques (Corkery [1]) to extract the coal. The coarse washery reject deposited above ground generates acidic drainage with associated elevated levels of some heavy metals. Acidic drainage associated with coal reject is not exclusive to Clarence, nor is it exclusive to coal mining. Acidic drainage is a significant problem for the international mining industry in general. At the time of the study Clarence Colliery was managed by Clarence Colliery Pty Limited. 
Much of the Western Blue Mountains drain into the Wollangambe River, which flows east through the Blue Mountains National Park to the Colo River and subsequently to the Hawkesbury River and Pacific Ocean. Pollution control measures are in place at Clarence, however, water treatment plants are very expensive to establish and operate. Neutralisation by placing a lime or fly ash additive into the reject material is uneconomical and unlikely to provide a long term management option as lime leaches out of the reject before neutralising the sulphides (Phipps et al. [2]). An alternative long term passive method for dealing with the reject at Clarence and its by-products is needed, post mine closure

Adjacent to Clarence Colliery is the Kable's Transport Pty. Ltd. sand mine, which produces a reject, of primarily silts, clays and fine sands. Restoration difficulties and reject disposal issues pose a problem here because of the voids created by the mining process and the poor structural stability of the tailings.

The aim of this project was to examine the feasibility, in the laboratory, of the co-disposal of colliery and sand-quarry reject by examining infiltration and percolation water quality. Advantages of co-disposal are:

A) Quarrying the sandstone creates large voids, leaving an area virtually impossible to restore to its original state. By co-disposing of the coarse coal reject with the sand mine reject the voids can be filled and shaped to resemble the natural topography of the land.

B) Chemical reactions between the coal reject and coarse and fine sand reject may reduce the acid generation sufficiently to comply with environmental guidelines.

C) Infiltration through the coal rejects may be significantly reduced due to the sand and clay reject filling the voids between the coal reject particles.

D) The reduction of oxygen and water input to the coarse reject, by reducing infiltration, will reduce the rate of acidic drainage.

E) The final material will have a higher structural stability than the separate reject, and the co-disposed reject may be more amenable to revegetation than the individual rejects.

F) Co-disposal of the reject materials is more cost efficient than importing materials from off site to treat acidic drainage and reshape the colliery and quarry after mining ceases.

Co-disposal of coal wastes has been tested and tried elsewhere (e.g. Morris and Williams [3], Surender and Petrik [4] and Benjamin et al. [5]) although not with slimes from a sand mining operation.

\section{Method}

In order to assess the most appropriate ratio of coarse reject to sand mining tailings for managing acidic drainage using co-disposal it was necessary to investigate a number of different ratios. Samples of $100 \%$ coal reject, sand and clay tailings were used as controls for the experiment. It was decided not to mix sand and clay tailings as the majority of Kable's reject are clay tailings. 
Furthermore, the complication of different ratios of sand and clay tailings would have produced an unmanageable experimental design.

The reject products and disposal options gave 22 experimental options. The percentage of coal reject by dry weight to each of the sand and clay, and for each co-disposal method was $100 \%, 90 \%, 80 \%, 70 \%, 50 \%, 20 \%$, and $0 \%$.

In summary, the experimental design was (Table 1)

- coal reject and either sand or clay and

- layered or mixed deposits.

Table 1: $\quad$ Experimental design.

\begin{tabular}{|c|c|c|c|c|}
\hline Drum No. & $\frac{\text { Deposition }}{\text { Method }}$ & \% Coal Reject & $\frac{\% \text { Sand }}{\text { Tailings }}$ & \% Clay Tailings \\
\hline 1 & Mixed & 50 & 0 & 50 \\
\hline 2 & Mixed & 70 & 0 & 30 \\
\hline 3 & Mixed & 76.3 & 0 & 23.7 \\
\hline 4 & Mixed & 90 & 0 & 10 \\
\hline 5 & Layered & 100 & 0 & 0 \\
\hline 6 & Layered & 0 & 100 & 0 \\
\hline 7 & Layered & 20 & 80 & 0 \\
\hline 8 & Layered & 50 & 50 & 0 \\
\hline 9 & Layered & 70 & 30 & 0 \\
\hline 10 & Layered & 80 & 20 & 0 \\
\hline 11 & Layered & 90 & 10 & 0 \\
\hline 12 & Mixed & 20 & 80 & 0 \\
\hline 13 & Mixed & 50 & 50 & 0 \\
\hline 14 & Mixed & 70 & 30 & 0 \\
\hline 15 & Mixed & 80 & 20 & 0 \\
\hline 16 & Mixed & 90 & 10 & 0 \\
\hline 17 & Layered & 20 & 0 & 80 \\
\hline 18 & Layered & 50 & 0 & 50 \\
\hline 19 & Layered & 70 & 0 & 30 \\
\hline 20 & Layered & 80 & 0 & 20 \\
\hline 21 & Layered & 90 & 0 & 10 \\
\hline 22 & Layered & 0 & 0 & 100 \\
\hline
\end{tabular}

Column experiments were undertaken to simulate field conditions. The 10$12 \mathrm{~mm}$ diameter material was placed in $205 \mathrm{~L}$ drums, having a diameter of $565 \mathrm{~mm}$, to ensure that edge effects of the drums were minimised.

The following water quality and hydrology parameters of the leachate were measured over time:

- $\mathrm{pH}$

- electrical conductivity 
- metals concentration

- leachate volume from the drum

- overflow volume from the top of the drum.

The following shows how the layers were deposited in each drum.

\begin{tabular}{|l|}
\hline Coal Reject \\
Coal Reject \\
Coal Reject \\
Coal Reject \\
Coal Reject \\
Coal Reject \\
Coal Reject \\
Coal Reject \\
Coal Reject \\
Sand/Clay tailings \\
\hline $90 \%$ Coal Reject, \\
$10 \%$ Sand/Clay \\
tailings \\
\hline
\end{tabular}

Coal Reject

Sand/Clay tailings

Coal Reject

Sand/Clay tailings

Coal Reject

Sand/Clay tailings

Coal Reject

Sand/Clay tailings

Coal Reject

Sand/Clay tailings

$50 \%$ Coal Reject, $50 \% \quad$ Sand/Clay tailings

\begin{tabular}{|l|}
\hline Coal Reject \\
Coal Reject \\
Coal Reject \\
Coal Reject \\
Sand/Clay tailings \\
Coal Reject \\
Coal Reject \\
Coal Reject \\
Coal Reject \\
Sand/Clay tailings \\
\hline $80 \%$ Coal Reject, \\
$20 \% \quad$ Sand/Clay \\
tailings \\
\hline
\end{tabular}

Coal Reject

Sand/Clay tailings

Sand/Clay tailings

Sand/Clay tailings

Sand/Clay tailings

Coal Reject

Sand/Clay tailings

Sand/Clay tailings

Sand/Clay tailings

Sand/Clay tailings

$20 \%$ Coal Reject,

$80 \% \quad$ Sand/Clay

tailings
Coal Reject

Coal Reject

Coal Reject

Sand/Clay tailings

Coal Reject

Coal Reject

Sand/Clay tailings

Coal Reject

Coal Reject

Sand/Clay tailings

$70 \%$ Coal Reject, $30 \% \quad$ Sand/Clay tailings

\section{Results}

Details of each experiment are not presented here as there is insufficient space. A summary of the results is presented. The results are grouped into four areas leachate chemistry, percolation, fabric of the deposits and shear strength.

\subsection{Leachate chemistry}

The study was carried out by placing the coal reject and sand mining tailings in $205 \mathrm{~L}$ drums either by layering or mixing. Deionised water was passed through 
the co-disposed material in a controlled and monitored manner. The rate of leaching and where relevant, overflow was recorded. The leachate was measured daily for $\mathrm{pH}$ and conductivity. Leachate samples were taken midway through the month and at the end of the month for metals analysis.

The study showed that co-disposal of coarse coal reject from Clarence Colliery with sand and clay tailings from Kable's Transport sand mine is a feasible option for managing acidic drainage. Layering $90 \%$ coal reject with $10 \%$ clay tailings produced leachate with $\mathrm{pH}$ above 5.0, leachate with conductivity below $250 \mu \mathrm{S} / \mathrm{cm}$, and over $90 \%$ overflow. Increasing the percentage of clay tailings in a coal reject and clay tailings layered system tended to increase the leachate $\mathrm{pH}$ and decrease the leachate conductivity.

Layering the coal reject with clay tailings limited the volume of water passing through the reject material as the clay tailings created a semi-impermeable barrier. By limiting the passage of water through the deposit the reject material is effectively saturated. Furthermore oxygen flux to the reject is eliminated and acid generation is prevented.

Layering the clay tailings with the coal reject raises the leachate $\mathrm{pH}$ and reduces the leachate metal concentration compared to the metal concentration in leachate from $100 \%$ coal reject or from coal reject co-disposed with sand tailings. It is likely that the leachate metal concentration from the coal reject layered with clay tailings options were lower due to the clay tailings tendency to adsorb toxic elements.

Determination of the metal load discharged from each co-disposal option indicated that co-disposal of coal reject with clay tailings by layering would produce leachate having the least impact upon receiving environments. The total metal load from these options was at most one tenth of that from the other three co-disposal modes.

An acid leaching experiment was conducted to assess the effect acid mine leachate has upon the sand and clay tailings. The results suggest that co-disposal of the coal reject with sand and clay tailings has only a minor benefit in raising leachate $\mathrm{pH}$ and therefore minimising metals concentration in the leachate.

\subsection{Percolation characteristics}

The percolation characteristics of the 19 original co-disposal options and the three control drums were investigated. The presence of preferred flow paths, movement of the material within the drums over the period of the column experiments and the development of oxidation staining was undertaken by analysing the fabric of the materials in the drums. Finally shear box tests using a large purpose built shear box were carried out on the reject in the three control drums and on the layered coal reject with clay tailings co-disposal options.

The experiment confirmed that layering 90\% coal reject with $10 \%$ clay tailings will reduce the impact of leachate through coal reject deposits upon receiving environments. It was found that the initial and constant percolation rates through coal reject layered with clay tailings are independent of the quantity of clay tailings and that the clay tailings layer creates a semi permeable barrier, reducing the total volume of water passing through the reject. Restricting 
the passage of water through the reject column served to saturate the coal reject, which in turn restricted access of oxygen to the reject. By eliminating oxygen, one of the key parameters of acid generation is eliminated, thus restricting the generation of acidic drainage.

\subsection{Fabric analysis}

Fabric analysis of the co-disposed material supported the leachate chemistry findings. The co-disposal options whose leachate chemistry indicated the formation of acidic drainage had a greater covering of oxidation stains than those whose leachate had higher $\mathrm{pH}$ and lower metals concentration. In all of the layered coal reject and clay tailings options the coal reject had sunk into the clay tailings, which in turn had seeped up the walls of the drum. The seepage has significant impact on implementation of a layered coal reject and clay tailings system in the field. The clay tailings layers must have sufficient thickness to allow for some seepage and inevitable thinning of the layer while maintaining its integrity and effectiveness as a barrier for water and oxygen movement through the deposit. No other significant disturbance of the reject material was noticed in any of the other co-disposal options.

\subsection{Shear strength}

Shear box testing showed layering the coal reject from Clarence Colliery with clay tailings from Kable's Transport Sand Mine produces a material having internal angle of friction of 20 to 30 degrees. Overall the material cohesion appeared to be low for the coal reject layered with clay tailings options, increasing as the percentage of coal reject increased.

Two difficulties arise from depositing the coal reject and clay tailings in a layered system. The first is how to get the coal reject to the middle of the clay tailings layer and then compact it to the required density. The second difficulty is sealing the sides of the deposit.

\section{Conclusion}

At Clarence an opportunity exists for developing methods for the management of acidic reject. Well known and established methods used in other parts of the world are not suited for implementation at Clarence. The steep and irregular topography of the site restricts the availability of land for management systems such as wetlands. Further more importation of additives and ongoing water collection and treatment is economically unviable for the long term.

A requirement of the mining lease at Clarence is restoration of the mine site to blend in with the natural bushland. Neither a wetland system nor use of a water treatment plant restore the site to its original condition. Co-disposal of the coarse reject with clay tailings by layering allows for disposal of the reject in such a way that the natural topography of the site is maintained while establishing a management strategy for the control of acidic drainage. 
Furthermore the voids created by the sand mining operation are an ideal location for the reject deposit.

Co-disposal of the coarse washery reject from Clarence Colliery with clay tailings from Kable's Transport sand mine has the potential to manage acidic drainage from the coal rejects. Layering the coal reject with clay tailings, minimum $10 \%$ clay tailings by volume, is the most promising technique for the landform and is recommended for field trials.

This study was intended to assess the feasibility of co-disposal of coarse coal washery reject with sand mining tailings at Clarence Colliery. It was not intended to be an extensive study but rather to highlight options that should be tried in the field and identify those options that would not be suitable for management of acidic drainage. The duration of the study was limited to one month followed by a second month of monitoring options that showed promising results. Comparison of the leachate chemistry results indicates a clear distinction between the leachate water quality for coal reject layered with clay tailings and the other three co-disposal modes. The study was sufficient to indicate that field trials co-disposing the coal reject with clay tailings by layering should be carried out.

The volume of clay tailings available from Kable's Transport sand mine is limited. At Clarence the fine coal tailings are blended with the washed coal product and sold. Disposal of the fine coal tailings at Clarence has not been allowed because of the ongoing management requirements for tailings dams and the difficulty involved in rehabilitating tailings dams. An alternative to the present mode of fine tailings disposal at Clarence may be co-disposing the tailings with the coarse reject. While co-disposal of tailings with coarse reject is not new, a more suitable method than the combined slurry pumping of the reject, as employed in several Queensland mines, may be found. The physical size characteristics of coal tailings are similar to those of clay. Filling the voids between coarse reject particles with tailings reduces the accessibility of water and oxygen through the reject deposit, thereby reducing the amount of leachate. However, $\mathrm{pH}$ and conductivity of the leachate would still be acidic. It may therefore be possible to utilise the fine coal tailings in a similar manner to the clay tailings, that is in a layer form to act as a barrier for the control of water and oxygen through the reject, thus reducing the generation of acidic drainage. Utilisation of the fine coal tailings would only restrict the passage of water and oxygen and not act to raise leachate $\mathrm{pH}$ or lower leachate metal concentration as the fine coal tailings do not possess the same sorbing tendency as the clay tailings.

Incorporation of fine coal tailings layers within the layered coal reject and clay tailings arrangement would have two advantages:

1. The volume of clay tailings available for co-disposal is restricted. Including the fine coal tailings in the system would increase the volume of fine material acting as a barrier to water and oxygen flux, and

2. Economic benefits are significant if the fine coal tailings are not blended with the washed coal product as the quality and sale price of the washed coal would increase. 
If the fine coal tailings are incorporated into the coal reject and clay tailings layered system the bottom layer must be clay tailings in order to allow the clay tailings to raise the $\mathrm{pH}$ and adsorb metals from the leachate before discharge into the Wollangambe River. If the bottom layer was fine coal tailings the discharge water would have higher $\mathrm{pH}$ and contain metals that entered the leachate as it passed through the lower coal reject layer.

Layering the coal reject with clay tailings created a semi-permeable barrier rather than filling the voids between he coal reject particles. The barrier acted to restrict percolation through the reject as well as reacting with the leachate to increase the leachate $\mathrm{pH}$ and adsorb metals. The rate of acidic drainage generation and leaching was reduced although the leachate water quality did not meet environmental guidelines. By layering the final reject deposit may be shaped to resemble the original landform. Although the structural stability of the final landform may not be as high as that for coal reject alone co-disposal of the coal reject with sand mining tailings will create a landform having greater stability than disposal of the sand mining tailings alone. The final landform should have sufficient stability to support native vegetation. The economic benefits of co-disposal are significant. The need for ongoing importation of chemicals to treat the leachate would be removed. Incorporating the fine coal tailings into the co-disposal system would remove them from the sold coal product, thereby increasing the quality of the coal product and generating a higher income for the colliery. Additionally incorporating the fine coal tailings into the co-disposal system will provide a greater volume of material that can be used to create a water and oxygen barrier within the reject deposit.

Results of this study suggest that co-disposal of coarse coal washery reject from Clarence Colliery with clay tailings from Kable's Transport sand mine is a feasible option for managing the generation of acidic drainage. Field trials for the management of acidic drainage by layering coarse coal reject with clay tailings should be carried out.

\section{Acknowledgements}

Mr Matthew de Groen, Mine Manager Kable's Transport, Officers of Clarence Colliery, and laboratory staff at UWS.

\section{References}

[1] Corkery, R.W. (1993). Statement of Environmental Effect in support of a review of the CCL 705 Emplacement Areas within the Clarence Colliery Pit Top Report No. 331/1. Orange: R.W.Corkery and Co Pty Ltd.

[2] Phipps, Tim T. Fletcher, Jerald J. and Skousen, Jeff G. (1995). A Methodology For Evaluating the Costs of Selective Handling of Overburden Materials. In Jeffrey G. Skousen and Paul F. Ziemkiewicz (Eds.), Acid Mine Drainage Control \& Treatment (pp.95-110). West Virginia University: National Mine Land Reclamation Centre. 
[3] Morris, P. H. and Williams, D. J. (1997) Results Of Field Trials Of CoDisposal Of Coarse And Fine Coal Wastes. Transactions of the Institution of Mining and Metallurgy, Section A - Mining Industry, 106: A38-A41.

[4] Surender, D. and Petrik, L. 2005. Development of a co-disposal protocol for the neutralisation and amelioration of acid mine drainage with fly ash. International Ash Utilisation Symposium, South Africa

[5] Benjamin E. Wickland, G. Ward Wilson, Dharma Wijewickreme, and Bern Klein 2006 Design and evaluation of mixtures of mine waste rock and tailings. Can. Geotech. J. 43(9): 928-945 